\title{
Google Classroom Uygulamasının Benimsenme Düzeyinin Belirlenmesi: Covid-19 Sürecinde Yozgat Bozok Üniversitesi (YOBÜ) Örneği
}

\author{
Zuhal Akgün ${ }^{1 *}$, Pınar Hacıhasanoğlu², Sena Saydam ${ }^{3}$ \\ 'YazarYozgat Bozok Üniversitesi, Meslek Yüksekokulu, İşletme Bölümü, Yozgat, Türkiye \\ ${ }^{2}$ YazarYozgat Bozok Üniversitesi, Meslek Yüksekokulu, Bankaclık Sigortaclık ve Finans Bölümü, Yozgat, Türkiye \\ ${ }^{3}$ YazarYozgat Bozok Üniversitesi, Meslek Yüksekokulu, Büro Yönetimi ve Yönetici Asistanlığı Bölümü, Yozgat, Türkiye \\ ORCID: Z. Akgün (0000-0002-5737-7920), P. Hacıhasanoğlu (0000-0002-4595-5156), S. Saydam (0000-0001-8120-9583)
}

\begin{abstract}
Özet: Bu çalışmada, dijitalleşmenin her alanda etkinliğinin arttığı günümüzde, önemli bir dijital uygulama olan Google Classroom uygulamasının benimsenme düzeyi araştırılmaktadır. Özellikle eğitim, toplantı, konferans gibi çeşitli etkinliklerin dijitale taşınmasında etkin rol oynayan bu teknolojinin kullanıcıları tarafından benimsenme düzeyi önem kazanmaktadır. Araştırmada, pandemi nedeniyle uzaktan eğitim zorunluluğunun doğal sonuçlarından biri olarak kullanılmaya başlanan Google Classroom’a yönelik Yozgat Bozok Üniversitesi öğrencileri ve öğretim elemanlarının algıları belirlenmeye çalışılmaktadır. Araştırmada nicel araştırma yöntemi ve veri toplama aracı olarak online anket tekniği kullanılmıştır. Davis (1989) tarafından geliştirilen Teknoloji Kabul Modeli çerçevesinde elde edilen veriler SPSS 20.0 paket programı kullanılarak analiz edilmiştir. Modelde yer alan bağımsız değişkenlerin bağımlı değişkenler üzerindeki etkisinin ortaya konulması amacıyla regresyon analizi yapılmıştır. Öğrenciler ve öğretim elemanlarından oluşan örneklem grupları ayrı ayrı değerlendirilmiştir. Yapılan analiz sonuçlarına göre model bünyesinde araştırılan tüm hipotezler kabul edilmiştir. Teknoloji Kabul Modeli değişkenleri yanında algılanan haz faktörünün, Google Classroom kullanımında etkisinin anlamlı ve pozitif olduğu belirlenmiş̧ir. Google Calssroom'un erişilebilirlik, etkin geri bildirim ve kullanıc dostu arayüzü gibi özelliklerinin algılanan kullanım kolaylığı ve hazzı anlamlı ve pozitif yönde etkilediği sonuçlar arasında yer almaktadır. Ayrıca öğrenci örnekleminde algılanan kullanım kolaylığı, öğretim üyesi örnekleminde algılanan zevk değişkenlerinin algılanan kullanışıılığı etkileyen en güçlü değişkenler olduğu görülmüştür. Dijital teknolojilerin farklı alanlarda benimsenme düzeyinin ölçülmesi ve çeşitli demografik faktörler açısından değerlendirme farklılıklarını konu alan çalışmaların yapılması önerilmektedir.
\end{abstract}

Anahtar Kelimeler: Dijitalleşme; Google Classroom; Uzaktan Eğitim; Teknoloji Kabul Modeli.

\section{Determining the Adoption Level of Google Classroom Application: Sample of Yozgat Bozok University (YOBU) During Covid-19}

\begin{abstract}
In this study, the adoption level of Google Classroom, which is an important digital application, is investigated in today's world, where the effectiveness of digitalization is increasing in every field. The level of adoption by the users of this technology, which plays an active role in transferring various activities such as education, meeting and conferences to digital, becomes important. In the research, it is tried to determine the perceptions of Yozgat Bozok University students and lecturers towards Google Classroom, which has started to be used as one of the natural consequences of the necessity of distance education due to the pandemic. In the research, quantitative research method and online survey technique was used as data collection tool. The data obtained from the online surveys developed for this purpose and prepared within the framework of the Technology Acceptance Model were analyzed statistically by SPSS 20.0. Regression analysis was conducted to reveal the effects of independent variables in the model on dependent variables. The sample groups consisting of students and academic staff were evaluated separately. According to the analysis results, all hypotheses investigated within the model were accepted. In addition to Technology Acceptance Model variables, the effect of perceived pleasure factor on Google Classroom activity was found to be significant and positive. It has been determined among the results that features of Google Classroom such as accessibility, effective feedback and user-friendly interface significantly and positively affect perceived ease of use and pleasure. In addition, it was observed that perceived ease of use in the student sample and perceived pleasure variables in the sample of academic staff were the strongest variables affecting perceived usefulness. It is recommended to measure the adoption level of digital technologies in different areas and to conduct studies on the differences in evaluation in terms of various demographic factors.
\end{abstract}

Keywords: Digitalization; Google Classroom; Technology Acceptance Model; Distance Education.

*Yazışma Adresi / Address for Correspondence:

Z. Akgün, Email: zuhal.akgun@bozok.edu.tr

Geliş Tarihi / Received Date: 24.03.2021

Kabul Tarihi / Accepted Date: 06.05.2021

Doi: $10.32329 /$ uad. 902325

\section{Giriș}

Günümüzde dijitalleşme, iletişimden hizmete, sağlıktan ekonomiye, eğitimden üretime ve daha birçok alanda yoğun bir şekilde kullanım alanı bulmaktadır. Özellikle hız, maliyet ve zaman gibi birçok açıdan avantajlar sağ- 
laması nedeniyle dijitalleșmenin önemi giderek daha da artmaktadır. Söz konusu kullanım alanlarından biri de eğitim sektörüdür. Mekân ve zaman sınırını ortadan kaldırarak eğitim bileşenlerinin bir araya gelmesini sağlaması nedeniyle son yıllarda ilgi odağı olduğu söylenebilmektedir. Dijitalleşme ve internetin gelişmesine paralel yeni teknolojiler ve yöntemler geliştirilmektedir. Google aracılığı ile 2014 yılında bu yeni teknoloji ve yöntemlerden birisi olarak geliştirilen Google Classroom (GC), eğitim alanında internet tabanlı ortak çalışma ortamı sunan bir uygulamadır. 2020'de, dünyanın dört bir yanındaki okullar COVID-19 nedeniyle uzaktan eğitime geçtiğinde Google Classroom'un kullanımının yoğun bir şekilde arttığı görülmektedir (Dykes, 2020). Dolayısı ile bu sürecin daha ne kadar devam edeceğine dair dünya genelinde belirsizliğin hala sürmesi bu ve buna benzer teknoloji kullanımlarının devam edeceği öngörülebilmektedir.

GC uygulamasının en önemli paydaşları eğitim-öğretim faaliyetlerinde rol alan aktörlerdir. Dolayısıyla bu uygulamanın belirlenen amaca hizmet edip etmediği ve hangi konularda hizmet sağladığı önemli bir konudur. Ayrıca GC uygulamasını kullananların uygulamaya yönelik benimseme düzeyleri ve uygulamadan beklentilerinin üzerinde durulması gereken önemli bir husus olduğu düşünülmektedir. Bu nedenle 2019-2020 bahar döneminde uzaktan eğitim sürecine giren ve dijital platformda eğitim-öğretim aracı olarak GC kullanan Yozgat Bozok Üniversitesi'nde yer alan öğretim elemanları ve öğrencilerin uygulamayı benimseme düzeyinin ortaya konulması, araștırmanın ana amacı olarak belirlenmiștir.

Çalışmada bu amaca hizmet eden Teknoloji Kabul Modeli (TKM) kullanılmış, model çerçevesinde GC benimsenme düzeyi araștırılmıştır. Model çerçevesinde GC'nin özelliklerinin hem öğrenci hem de öğretim elemanı açısından algılanan kullanım kolaylığı ve algılanan haz üzerindeki etkisi ortaya konulmaya çalışılmaktadır. Ayrıca algılanan kullanım kolaylığı ve algılanan haz değişkenlerinin algılanan kullanışlılık ve algılanan niyet üzerinde etkisinin olup olmadığı araştırma kapsamında oluşturulan model ile test edilmektedir. Bu araștırma ile $\mathrm{GC}$ ve benzeri dijital uygulamaların geliştirilmesine katkı sağlanması diğer amaçlar arasında yer almaktadır. Çalışmanın, algılanan kullanım kolaylığı, algılanan haz, algılanan kullanışlılık ve algılanan niyet değişkenleri açısından mevcut durumun ortaya konulması, dijital uygulamaların benimsenme düzeyinin belirlenmesi ve pandemi süreci ve sonrası için kullanım alanlarının genişletilmesi noktasında literatüre katkı sağlayacağı düşünülmektedir.

\section{KAVRAMSAL ÇERÇEVE}

\subsection{Dijital Dönüşüm}

Yaşamın her alanında olduğu gibi bilginin devamlı yenilenmeye duyduğu ihtiyacı açıklamak, eğitim- öğretim kurumlarının biçim ve içerik dönüșümünü ifade etmeye katkı sağlamaktadır (Garda \& Temizel, 2016). Teknolojik gelişmeler ve çıktısı olan cihazlar, çağın hızını yakalamak ve gerekliliklerine uyum sağlamak noktasında etkili olmaktadır. Teknoloji, insan yaşamına dair faaliyetlerin tamamını kapsayan sağlık, eğitim, politika ve sosyal hayat üzerinde etki yaratmaktadır. Yaşamsal açıdan yüksek önem arz eden eğitim de, öğrenme ve öğretme süreci içerisinde zenginleștirmiş ve zenginleștirmeye devam eden yeni anlayış ve yeni kavramlarla teknolojik gelişmelerin çekim alanında yer almaktadır (Korucu \& Biçer, 2019). İletişim olanaklarının artması, eğitim faaliyetlerinin yaygınlaşmasında ağırlıklı rol oynamaktadır. Teknoloji ve internet, nesilleri yetiştiren ve geleceğe hazırlayan toplumsal şekillenmenin bir parçası olarak eğitim hayatını etkilemektedir (Sarıtaş \& Barutçu, 2020).

İnternet kullanımında, yıldan yıla görülen artışı (Internet World Stats, 2020), internetin eğitim mecralarındaki nüfuzu ile açılamak mümkündür. Günümüz dünyası, sözlükler, makaleler ve arşivler, dijital kütüphaneler, elektronik ansiklopediler, dijital kitaplar, bloglar, tartışma forumları, sosyal ağlar ve web sayfaları aracılığı ile bilgiye erişim imkânı sunulmaktadır. Dijital dönüşümler, bilgiye ulaşma ve bilgiyi dağıtma hususunda barındırdığı özelliklerle, mevcut dönemi tüm dönemlerden ayırmaktadır (Taşkıran, 2017).

\subsection{Uzaktan Eğitim ve Google Classroom Uygulaması}

İçinde bulunduğumuz dijital dönemde, uydu, fiber optik, radyo, televizyon, bilgisayar, internet ve bilişim teknolojilerinde görülen ilerleme, eğitimin iç dinamiğine yansiyarak, yenilikçi eğitim yaklaşımlarını inşa etmektedir. Yenilikçi eğitim modellerinden biri olan uzaktan eğitim modeli, ilk olarak 1728 'de posta yolu ile uygulama alanı bulmuştur. Bugün bilişim teknolojilerinde yaşanan gelişmeler, telekonferans ve sayıca giderek artan internet uygulamaları ile hayatımızda yeni bir sayfa açmaktadır. Uzaktan eğitim uygulamaları ile öğrenen ve öğretenler, mekânsal ayrılığa karşın birbirleri ile görüntülü ve sesli olarak iletişim halinde kalabilmektedir (İşman, 2005). Teknolojinin dijitalleşmesiyle eğitim mecralarının bu sürece hızla entegre olduğu görülmektedir. Eğitim, dijital dönüşümün yarattığı çevrim içi öğrenme ortamlarına evirilmekte ve çevrim içi öğrenme, inovatif eğitimin altyapısını oluşturarak, sunduğu yeni hizmetlerle öğrenen ve öğretenlerin ilgisini çekmektedir (Tekin Poyraz \& Özkul, 2019). Toplumsal hedef düşünüldüğünde, uzaktan eğitim, bu sürecin bir öğesi ve aracı olarak görülmektedir (Akyürek, 2020).

Uzaktan eğitim "öğrencileri, kaynakları ve eğitmenleri birbirine bağlamak için etkileşimli telekomünikasyon sistemlerinin kullanıldığı kurum tabanlı, resmi eğitimdir". Erişilebilirlik ve rahatlık, bu eğitim tarzının önemli avantajlarıdır (Simonson vd., 2011). Uzaktan eğitim, yüz yüze eğitimle ilişkili coğrafi ve zaman kısıtlamalardan arınmıș teknolojiyi kullanan bir sistemdir. Uzaktan 
eğitim, teknoloji ile sağlanan eğitime geçmeye hizmet eden, daha önce kullanılmayan pazarlama segmentlerini hedefleyen, öğretim ve öğrenmeye yönelik esnek ve yenilikçi yaklaşımlar geliştiren ve öğrencileri küresel teknoloji odaklı bir toplumda istihdama hazırlayan fırsatları sunmak için konumlandırılmıştır (Tabata \& Johnsrud, 2008).

Uşun'a göre uzaktan eğitim; öğrenme ve öğretme faaliyetinin, kaynak ile alıcıların birbirinden ayrı olduğu fiziki bir mekânda, kaynağın alıcısına 'bireysellik', 'esneklik', 'bağımsızlık' imkânı sunduğu, teknoloji ve yöntem desteği sağlanarak kaynak ve alıcının etkileşimli tümleşik teknoloji yardımı ile iletişimde bulunmasına olanak tanıyan, sistematik bir eğitim teknolojisi uygulamasıdır (Arat \&Bakan, 2011).

Telli Yamamoto \& Altun (2020), COVID-19 nedeni ile ilan edilen küresel pandemide, tüm dünya ülkelerinin eğitim ve yükseköğretim sistemlerinde, salgının etkilerinin yayılmasını önlemek amacı ile uzaktan eğitime geçişini dünyadan örnekler ile ortaya koymaktadır. Çalışmada, Çin'in, İtalya'nın, ABD’nin, İngiltere'nin, Türkiye'nin eğitim ve öğretimin aksamaması ve dolayısıyla salgının yavaşlatılması noktasında sürdürdükleri ülke uygulamalarına yer verilmektedir. Araştırmaya göre, pandemi ile beraber hızlı bir uyum süreci yakalanmaya çalışılmıştır. Süreç deneyimlerine göre, yakın gelecekte ana öğrenmenin dijital öğrenme haline evirileceği öngörülmektedir.

Dijital dönüşümün iletişim mecralarına sağladığ 1 imkânlar, pek çok öğrenme yöntemleri üzerinde öğrenmeyi kolaylaştırıcı yönü ile hem fiziki sınıf hem de sanal sınıflarda varlığını göstermektedir. Eğitimin dijitalleşme yolculuğunda kullanılan bazı dijital teknolojiler aşağıdaki başlıklarla tasnif edilebilmektedir (Ünlü, 2019);

- Ses ve video akışı

- Çevrim-içi öğrenme yönetim sistemleri (Blackboard Learn, Blackboard Collaborate, Moodle, D2L, Canvas, Adobe Connect, GoToMeeting, Microsoft Teams vb.)

- Ders kayit teknolojileri (podcast'ler için GarageBand veya Audacity ve Echo360 vb.)

- Tabletler ve mobil cihazlar (iPad, cep telefonu vb.) ve bunlarda çalışan uygulamalar

- Wiki, WordPress vb. blog hazırlama yazılımlarını içeren MediaWiki, Google Hangouts, Google Dokümanlar ve Twitter vb. sosyal medya uygulamaları

- Google Arama, Google Çeviri vb. arama motorlarıve çeviri araçları

- Mobil ve artırılmış gerçeklik araçları vb.

Küresel düzeyde kullanımı ve buna bağlı olarak etki çemberi yaygın olan Google, kişisel gelişim, iş hayatı, eğlence, eğitim gibi pek çok çeşitli alanda faaliyet göstermektedir. Google'ın hizmet sağlayıcıları arasında en az bilinen ve henüz yaygınlaşmakta olan alan eğitimdir (Poyraz \& Özkul, 2019). Eğitim alanında etkinliğini arttırmak amacıyla Google tarafından 2014 yılında geliștirilen Google Classroom, ücretsiz, internet tabanlı bir ortak çalışma aracıdır. Bir Google hesabıyla, eğitimciler platformu sanal bir sınıf oluşturmak, öğrencileri canlı eğitime katılmaya davet etmek ve öğrencilerin notlarını kaydetmek için kullanabilmektedir. GC'nin temel amacı, kullanıcılar arasında dosya paylaşma sürecini basitleştirmek ve kolaylaştırmaktır. Dokümanların Meet, Drive, E-Tablolar gibi Google'ın farklı araçlarına entegrasyonuda mümkündür. 2020'de, dünyanın dört bir yanındaki okullar COVID-19 nedeniyle uzaktan öğrenmeye geçtiğinde Classroom kullanımının keskin bir șekilde arttığı görülmektedir (Dykes, 2020). Google Classroom, pedagojik, sosyal ve teknolojik olanaklar sunan benzersiz yerleşik işlevleri nedeniyle öğretme ve öğrenme potansiyeline sahip popüler bir Web 2.0 aracıdır. Öğretmenlerin ödevleri hızlı bir şekilde oluşturup düzenlemesini, verimli bir şekilde geri bildirim sağlamasını ve sınıflarıyla kolaylıkla iletişim kurmasını kolaylaştırmaktadır (Sudarsana vd., 2019).

Literatürde GC'yi araştırma konusu olarak ele alan birçok çalışma bulunmaktadır. Azhar \& Iqbal (2018), öğretmenlerin $\mathrm{GC}^{\prime}$ nin etkililiğine ilişkin algısını değerlendirmeyi amaçladığı çalışmada, öğretmenler açısından GC'nin öğretim metodolojileri üzerinde önemli bir etkiye sahip olmadığı, belge yönetimi ve temel sınıf yönetimi için kullanılabilecek bir kolaylaştırma aracı olarak algıladıkları ortaya konulmuştur. Heggart \& Yoo (2018), son sınıf ilköğretim öğretmenliği öğrencilerinin GC'yi kullanma ve platformun gelecekteki eğitim bilimini nasıl etkileyebileceğini değerlendirmek istemişlerdir. Araştırmalarında GC'nin öğrenci katılımını, öğrenmeyi ve sınıf dinamiklerini iyileştirdiğini ortaya koymuşlardır. Bhat vd. (2018), teknolojinin sınıf öğrenimine dâhil edilmesini, sınıfta bu teknolojiden yararlanmanın çeşitli yollarını, faydalarını ve bir dizi ilgili konuyu araştırmışlardır. Çalışmalarında, öğretmenler açısından GC sayesinde yapılan ödevlerin etkinlik düzeyinin manuele göre çok daha başarılı olduğunu ifade etmişlerdir. Sudarsana vd. (2019)'e göre GC, Endonezya' da öğrencilerle iletişim kurmak, ödev vermek ve geri bildirim için merkezi bir mekân olarak tanımlanmıştır. Poyraz \& Özkul (2019), eğitim için Google (Google for Education) platformunu incelediği çalışmada, bir öğrenme ortamı olan Google Sınıf (Google Classroom)'ın sağladığı olanakları, platformun güçlü ve zayıf yönlerini, kullanıcı tecrübelerini ve geleceğine dair izlenimlerini ortaya koymuştur. Gupta \& Pathania (2021), Google Classroom'un öğretme ve öğrenme düzeyindeki etkisini araştırdığı çalışmada, öğrencilerin öğrenme etkinliklerine kolayca erişebildiklerini, dersteki diğer öğrencilerle elektronik ortamda iletişim kurabildiklerini, ne zaman öğrenmek istediklerine karar verme ve bunu ayarlama özgürlüğüne sahip olduklarını ortaya koymuştur. Sonuçlar ayrıca öğrencilerin çevrimiçi kaynaklara düzenli olarak erişebildiklerini ve öğretmenleri- 
ne neyi anlamadıklarını sorma özerkliğine sahip olduklarını belirlemiştir. Literatürde, GC'nin TKM çerçevesinde benimseme düzeyini araştıran bir çalışmaya rastlanmamıștır. Bu yönüyle çalışmanın özgün nitelikte olduğu düşünülmektedir.

\subsection{Teknoloji Kabul Modeli (TKM)}

Bireyler tarafından teknolojinin kabulünü tahmin etmek ve açıklamak amacıyla, 1989' da Davis tarafından Teknoloji Kabul Modeli (TKM) geliştirilmiştir (Balog \& Pribeanu, 2010). TKM, çoğunlukla bilgi sistemleri alanında en etkili ve yaygın teori olarak düşünülmüş ve zengin deneysel çalışmalar aracılığıyla kabul edilmiştir. TKM tutumun davranışı nasıl etkilediğini tartışan Sebepli Davranış Teorisine dayanmaktadır (Chang vd., 2010). Bu model, bir teknolojiyi kullanma konusundaki davranışsal niyetin, algılanan kullanım kolaylığı ve algılanan kullanışlılık olmak üzere iki temel inanca bağlı olduğu varsayımı üzerine kurulmuştur (Balog \& Pribeanu, 2010).

TKM, dış değişkenlerin, içsel değișkenler olan inancı, tutumu ve kullanma niyetini nasıl etkilediğini ortaya çıkarmak için bir temel sağlamaktadır. TKM' ye göre, bir teknolojik sistemin gerçek kullanımı, doğrudan veya dolaylı olarak kullanııının davranıșsal niyetlerinden, tutumundan, sistemin algılanan kullanışlılığından ve algılanan kullanım kolaylı̆̆ından etkilenmektedir. TKM ayrıca, dış faktörlerin, algılanan kullanışlılık ve algılanan kullanım kolaylığı üzerindeki dolaylı etkiler yoluyla niyeti ve fiili kullanımı etkilediğini ileri sürmektedir (Park, 2009). Davis vd. 1992'de modele içsel bir motivasyon faktörü olarak algılanan hazzı ekleyerek modeli güncellemiştir (Balog \& Pribeanu, 2010).

Geliştirilen TKM ile teknolojik uygulamaların sağladığı kullanışlılık, kullanım kolaylığı ve haz gibi faktörler sayesinde kişilerin teknolojileri kullanma davranışlarına katkısı ortaya konulmaktadır. Farklı sektörlerde yapılmış çeşitli çalışmalar bu durumu doğrulamaktadır. Bu yüzden yeni uygulamaların tüketiciler tarafından nasıl karşılanacağını ve uyum sağlanacağını anlayabilmek için TKM' ye ihtiyaç duyulmaktadır (Uyar, 2019).

Aşağıda Teknoloji Kabul Model'inden yola çıkılarak geliştirilen, araștırma modelinde bulunan faktörler ve aralarındaki ilişkiler ayrıntılı olarak açıklanmaktadır.

\subsubsection{Dişsal Değiş̧kenler}

TKM'de algılanan kullanım kolaylığı ve algılanan kullanışlılık üzerinde etkili olduğu belirtilen dışsal değişkenler, sistemin kullanılma derecesini ve kullanıcı davranışını etkileyen özellikleri tanımlamaktadır. Bu faktörler, sistem özellikleri ve tasarımı, kullanıcının özellikleri (bilişsel ve kişilik) veya davranışa özgü dışsal değişkenleri kapsayan özelliklerdir (Davis, 1989). Dışsal değişkenlerin TKM modelinde kullanıldığı bazı çalışmalarda, içerik kalitesi (Park, 2012), tasarım (Kim, 2012), kişiselleştirme, işbirliği ortamı (Lee, 2014), etkileşim, anında bağlantı (Shin, 2016), bağlantı ortamı (esneklik), iletişim ve bilgi paylaşımı (entegrasyon) gibi özellikler dıșsal değișken olarak kullanılmıștır (Hong \& Yu, 2018). Bu çalışmada dışsal değişken olarak Google Classrooom uygulamasının özellikleri kullanılmıștır. Google Classroom, yükseköğretimde önemli ve popüler bir sınıf yönetimi uygulaması olan ücretsiz web tabanlı bir platformdur. Sinıf oluşturma, düzenli iletişim kurma, dosya ve bilgi paylaşımı, duyuru yapma gibi etkileşim oranı yüksek bir uygulamadır (Fitriningtiyas vd. 2019). Bu noktadan hareketle Google Classroom Özellikleri (GCÖ), kullanıcıların uygulama hakkında olumlu veya olumsuz algılamalar geliştirmelerine yardımcı olabilecek donanım ve araçların bütünü olarak ifade edilebilir. Çalışmada, GC'nin kullanıcılarına sunduğu, dışsal değişken olarak değerlendirilen bu özellikler şöyle sıralanmaktadır (Pappas, 2015);

- Tüm dijital cihazlardan erişilebilir olması (anında bağlant1),

- Etkili bir iletişim ve paylaşım imkânı sunması (bilgi paylaşımı),

- Ödev vb. dokümanların hızlı bir şekilde iletilmesi ve aynı hızla geri bildirimlerin alınması,

- Geri bildirimler sayesinde sorular ve yorumlara çevrimiçi desteğin sağlanması(etkileşim),

- Temiz ve kullanıcı dostu ara yüz (tasarım),

- Herkesin erişimine açık olması (esneklik).

Literatürde dijital teknolojilerin algilanma düzeyinin, algılanan kullanım kolaylı̆̆ı, algılanan haz ve algılanan kullanışllılı olmak üzerine birçok faktör üzerinde etkilerini araştıran çeşitli çalışmalar bulunmaktadır (Al-Aulamie vd., 2012; Al-Maroof \& Al-Emran, 2018; Balog \& Pribeanu, 2010; Chen vd., 2013; Yang vd., 2011).

\subsubsection{Algilanan $\mathrm{Haz}(\mathrm{AH})$}

Kullanıcı yeni teknolojiyi benimseyerek haz alabildiğinde, benimsemeye yönelik olumlu tutum da sergilemektedir. Kişi aynı zamanda eğlenceli olmayan aktiviteye kıyasla, daha keyifli olan bir aktiviteyi yapmak veya tekrarlamak için de daha motive olmaktadır (Suki \& Suki, 2011). Algılanan haz, seçilen teknoloji ile ilgili beklenilen performans sonuçları dişında, söz konusu teknolojinin kullanılmasının kendi başına ne kadar yüksek zevk verdiğinin algılanması olarak ifade edilmektedir. Başka bir ifade ile ulaşılması beklenen sonuçların dışında, sonuca ulaşmak için bu teknolojinin (aracın) kullanımından kaynaklanan zevk düzeyi olarak tanımlanmaktadır. Algılanan hazz, içsel bir motivasyon kaynağı olarak zevk ve içsel memnuniyet temeline dayanmaktadır (Balog \& Pribeanu, 2010). Literatürde dijital teknolojiler ile ilgili TKM kullanılarak, algılanan hazzın, algılanan kullanışlllık üzerinde pozitif yönde etkisinin olduğu sonucunu ortaya koyan çeşitli çalışmalar bulunmaktadır (Al-Aulamie vd., 2012; Balog \& Pribeanu, 2010; Lee vd., 2005). 


\subsubsection{Algılanan Kullanım Kolaylığı (AKK)}

Bireylerin bir sistemi fazla çaba sarf etmeden kullanabilecekleri inancı taşımaları algılanan kullanım kolaylı̆̆ı (AKK) olarak ifade edilmektedir. Diğer her şey eşit oldugunda, kullanımı daha kolay olarak algılanan bir uygulamanın kullanıcılar tarafından kabul edilme olasılığının daha yüksek olduğu iddia edilmektedir (Davis, 1989). Davis (1989) AKK'nın aslında AK için önemli bir bağımsız faktör olabileceğini öne sürmektedir. TKM, AKK'nın bir sistemi kullanmaya yönelik tutumun önemli bir belirleyicisi olduğunu varsaymaktadır. Daha sonra yapılan çalışmalarda hem AKK'nın hem de AK'nın sistem kullanımının önemli belirleyicileri olduğu kanıtlanmıştır (Chen vd., 2013). Algılanan kullanım kolaylığının (AKK) hem alg1lanan kullanışlılık (AK) hem de davranışa yönelik niyeti doğrudan etkilediği birçok çalışmada ortaya konulmaktadır (Al-Maroof \& Al-Emran, 2018, Balog \& Pribeanu, 2010; Chen vd., 2013).

\subsubsection{Algılanan Kullanışlılık (AK)}

Bireylerin belirli bir sistemi kullanarak iş performanslarını arttırabileceklerine inanma derecesi algılanan kullanışlılık olarak tanımlanmaktadır. AK açısından üst düzey bir sistem, kullanıcının olumlu bir kullanımperformans ilişkisinin varlığına inandığı sistemdir (Davis, 1989). İnsanlar davranışlarının sonuçlarını AK açısından değerlendirmekte ve davranış seçimlerini sistemin kullanışlılığına dayandırmaktadırlar (Chen vd., 2013). Algılanan kullanışlılığın davranışsal niyet üzerinde pozitif etkiye sahip olduğu çeşitli çalışmalarla kanıtlanmıştır (Al-Aulamie vd., 2012; Al-Maroof \& Al-Emran, 2018; Balog \& Pribeanu, 2010; Chen vd., 2013; Lee vd., 2005; Shaharanee vd., 2016).

\subsubsection{Algılanan Niyet (AN)}

İnsanların bir davranışı gerçekleștirmek için ne kadar çaba göstermeyi planladıklarını ve ne kadar denemek istediklerini yansitan odak nokta niyet olarak ifade edilmektedir. Bu nedenle, bir bireyin bir davranışı gerçekleştirme niyeti ne kadar güçlüyse, davranış o kadar büyük olasılıkla hayata geçirilecektir (Limayem vd., 2001). Davranışsal niyet kişinin uygulamayı benimseme olasılığının bir ölçüsü olarak ifade edilebilir (Mubuke vd., 2017). TKM'ye göre, algılanan niyet, belirli bir bilgi teknolojisi sisteminin gerçek kullanımını tanımlamakta ve bu nedenle teknoloji kabulünü belirlemektedir (Alharbi \& Drew, 2014).

\section{TEKNOLOJI KABUL MODELI İLE İLGILI LITERATÜR ARAŞTIRMASI}

Lee vd. (2005), yaptıkları çalışmada öğrencilerin İnternet Tabanlı Öğrenme Aracını (IÖA) kabul edip etmediklerini araştırmışlardır. Çalışmada teknoloji kabul modeline, öğrencilerin yeni öğrenme ortamını kullanma niyetini açıklamak için hem dışsal (algılanan kullanışlılık ve kullanım kolaylığı) hem de içsel (algılanan haz) motivasyon faktörlerini eklemişlerdir. Sonuçlar, hem algılanan kullanışlılık hem de algılanan hazzın önemli ölçüde ve doğrudan İÖA kullanma niyetlerini etkilediğini göstermiștir. Algılanan kullanım kolaylığının ise, öğrencilerin İÖA kullanımına yönelik tutumu veya niyeti üzerinde anlamlı bir etki yaratmadığı tespit edilmiştir.

Balog \& Pribeanu (2010) tarafından yapılan araştırma, algılanan hazzın öğrencilerin Arttırılmış Gerçeklik Öğrenme Platformunu (AGÖP) kabul etmelerindeki rolünü araştıran az sayıdaki çalışmadan birisidir. Çalışmanın modelinde, öğrencilerin yeni bir öğrenme aracını kullanma niyetini açıklamak için hem dişsal hem de içsel faktörlerden yararlanılmıștır. Araştırma sonuçları, AGÖP'nin ergonomik özelliklerinin AKK ve AH'yı pozitif etkilediği, AK ve AH'nın, AGÖP kullanma davranışsal niyetini önemli ölçüde etkilediği, ancak algılanan kullanım kolaylığının önemli bir öncül olmadığını göstermiştir. Bununla birlikte AKK'nın AK ve AH üzerinde anlamlı ve pozitif bir etkiye sahip olduğu çalışma sonucunda ortaya konulmuştur. Ayrıca algılanan hazzın AGÖP'yi kullanma niyetini etkileyen kilit bir faktör olduğu kanıtlanmıştır.

Yang vd. (2011) yaptıkları çalışmada kişilerin Dijital Öğrenme Sistemini (DÖS) kabul düzeylerini belirlemek için TKM kullanmışlardır. Tayvan'daki 120 üniversite öğrencisi örneklem olarak alınmış, araştırmada yapısal eşitlik modeli kullanılmış ve çalışma TKM'nin dijital öğrenme bağlamındaki etkinliğini doğrulamıștır. Diğer taraftan, sonuçlar DÖS’nin içeriğinin ve interaktif hizmetinin AKK üzerinde doğrudan bir etkiye sahip olduğunu göstermektedir. Ayrıca, DÖS'nin interaktif hizmetinin AK üzerinde de doğrudan etkisi olmaktadır. Hem AKK hem de AK, DÖS' ye karşı tutumu önemli ölçüde ve olumlu yönde etkilemektedir.

Al-Aulamie vd. (2012) TKM'ye dayanan çalışmalarında, e-öğrenme sistemleri bağlamında genişletilmiş bir model tasarlamışlardır. Önerilen modele, haz ve bilgisayar oyunculuğu faktörlerini eklemişlerdir. Araştırma sonuçları algılanan kullanışlılığın davranışsal niyet için en güçlü belirleyici olduğunu göstermektedir. Ayrıca, haz ve diğer değişkenler, algılanan kullanışlılık üzerinde önemli bir etki göstermiştir.

Chen vd. (2013)'nin yaptıkları çalışmanın amacı, üniversite öğrencilerinin Web Tabanlı Öğretim (WTÖ) sistemlerini kullanma konusundaki davranışsal niyetlerini etkileyen faktörleri araştırmak ve buna bağlı olarak bu sistemleri kullanma niyetlerini tahmin etmek için kapsamlı bir model geliştirmektir. Bu amaca ulaşmak için Tayvan'daki bir meslek yüksekokulunda dersleri desteklemek için bir WTÖ sistemi temin edilmiştir. TKM, Akıl Yürütme Teorisi (AYT) ve Sosyal Bilişsel Teori (SBT) kavramlarından yararlanan çalışmada, üniversite öğrencilerinin WTÖ platformunu kullanma niyetini ölçmek için bir yol geliştirilmiştir. Ampirik sonuçlara göre AH, AKK ve Sistem Özelliklerinin, AK üzerinde pozitif yönlü etkisi olduğu ve AK'nın da davranıșsal niyet üzerinde 
olumlu etkisi olduğu kanıtlanmıştır. Öğrencilerin web tabanlı öğrenme aktiviteleri için sisteme karşı pozitif niyetler gösterdiğini ve uzun vadede kullanımından olası bir fayda sağladıklarını göstermektedir.

Shaharanee vd. (2016) çalışmalarında, Karar Bilimleri programı kapsamında veri madenciliği konusu için, Google Classroom'un aktif öğrenme faaliyetlerinin etkinliğini, analizini ve değerlendirmesini ortaya koymayı amaçlamıșlardır. Öğrenme faaliyetlerinin etkinliğini ölçmek için TKM kullanılmıștır. Bu çalıșmada, veri madenciliği dersini alan 100 öğrencinin anketlere verdiği yanıtlar değerlendirmeye alınmıştır. Sonuçlar, öğrencilerin çoğunun sınıfta tanıtılan Google Classroom'dan memnun olduğunu göstermiştir. Analiz edilen verilerin sonuçları, tüm oranların ortalamanın üzerinde olduğunu göstermiştir. Özellikle, AKK, AK, iletişim ve etkileşim, öğretim sunumu ve öğrencilerin Google Classroom'un aktif öğrenme faaliyetlerine karşı memnuniyet düzeylerinin yüksek olduğu sonucu ortaya konulmuştur.

Al-Maroof \& Al-Emran (2018) çalışmalarında, Umman'daki Al Buraimi University College'deki (BUC) öğrencilerin Google Clasroom'u kabul etmelerini etkileyen faktörleri incelemeyi amaçlamışlardır. Çalışmanın hipotezlerini formüle etmek için TKM benimsenmiștir. Çalıșmanın sonuçları, hem AKK hem de AK'nın davranışsal niyeti pozitif yönde etkilediğini ve bunun da Google Classroom' un gerçek kullanımını etkilediğini kanıtlamaktadır. Ayrıca AKK'nın AK'yı pozitif yönde etkilediği çalışmanın diğer sonuçları arasındadır.

\section{ARAŞTIRMANIN YÖNTEMI}

COVID-19 pandemisi beraberinde tüm dünyada ve Türkiye'de uzaktan eğitim uygulamalarının zorunlu hale gelmesi ile dijital öğrenme ve öğretme uygulamaları önem kazanmıștır. Bu uygulamalardan biri olan Google Classroom uygulamasının benimsenme düzeyini belirlemek araştırmanın amacını oluşturmaktadır. Çalışmanın ana kütlesini Yozgat Bozok Üniversitesi (YOBÜ) öğrenci ve öğretim elemanları oluşmaktadır. Araştırmada nicel araştırma yöntemi ve veri toplama aracı olarak online anket tekniği kullanılmıştır. Haziran-Temmuz ayları arasında toplanan veriler ve model çerçevesinde oluștu- rulan hipotezler regresyon analizi ile istatistikî açıdan değerlendirilmiştir. Uzaktan eğitim süreci nedeniyle online yapılan anketlerin katılımcılara ulaştırılması, çeşitli sosyal platformlar ve YOBÜ Bilgi İșlem Daire Başkanlığı'nın katkıları sayesinde sisteme kayıtlı bozok.edu.tr-yobu.edu.tr uzantılı tüm elektronik posta adresleri aracıllğı ile gerçekleştirilmiştir. Örnekleme yöntemi olarak tesadüfî olmayan kolayda örnekleme yöntemi kullanılmıștır. Kolayda örnekleme; ana kütle içerisinden seçilecek birimin görüşmeciye bırakıldığı yöntemdir (Haşıloğlu vd. 2015). Gönüllülük esasına göre yapılan anket çalışması sonucu öğrenci anketlerinden 488 'i, öğretim elemanı anketlerinden 124'ü analiz için kullanılmıștır. İki örneklem birimi için ayrı ayrı yapılan analizler her iki kullanıcı kesimi için GC benimsenme düzeyinin karşılaştırılması imkânını da sunmuştur.

Araştırmada kullanılan anket formu, demografik özellikleri belirlemeye yönelik bölüm ve TKM çerçevesinde Balog \& Pribeanu (2010), Pappas (2015), Shaharanee vd. (2016), çalışmalarından uyarlanan, 5'li likert ölçekle değerlendirilen GCÖ (Google Classroom Özellikleri), AKK (Algılanan Kullanım Kolaylığı), AH (Algılanan Haz), AK (Algılanan Kullanışlılık) ve AN (Algılanan Niyet) ifadelerinin yer aldığı iki bölümden oluşmaktadır.

\subsection{Araştırmanın Hipotezleri}

$\mathbf{H}_{1}$ : Google Classroom'un algılanan kullanışlılığı, Google Classroom'a yönelik algılanan niyeti etkiler.

$\mathrm{H}_{1 \mathrm{a}}$ : Google Classroom'un algılanan kullanışlılığı, öğrencilerin Google Classroom'a yönelik algılanan niyetini etkiler.

$\mathrm{H}_{1 \mathrm{~b}}$ : Google Classroom'un algılanan kullanışlılığı, öğretim elemanlarının Google Classroom’a yönelik algılanan niyetini etkiler.

$\mathbf{H}_{2}$ : Google Classroom'un algılanan kullanım kolayl-ğı, Google Classroom’a yönelik algılanan kullanışlılığı etkiler.

$\mathrm{H}_{2 \mathrm{a}}$ : Google Classroom'un algilanan kullanım kolayl1ğı, öğrencilerin Google Classroom’a yönelik algılanan kullanışlılığını etkiler.

$\mathrm{H}_{2 \mathrm{~b}}$ : Google Classroom'un algılanan kullanım kolaylı-

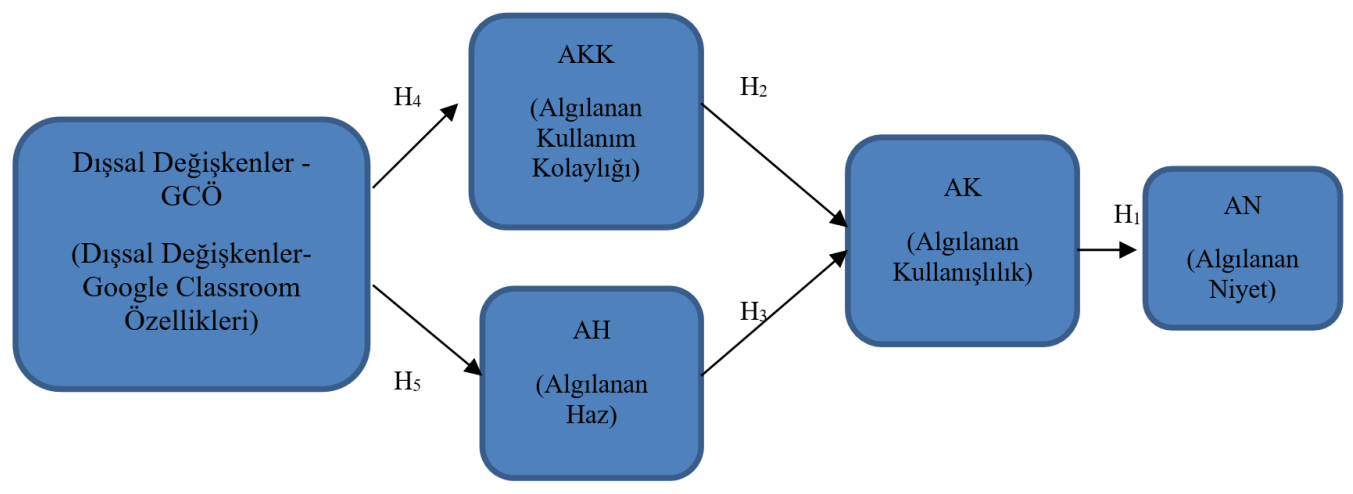

Şekil 1. Araştırmanın Modeli 
ğı, öğretim elemanlarının Google Classroom'a yönelik algılanan kullanışlılığını etkiler.

$\mathbf{H}_{3}$ : Google Classroom'u kullanmaya yönelik algılanan haz, Google Classroom'a yönelik algılanan kullanışlılığı etkiler.

$\mathrm{H}_{3 \mathrm{a}}$ :Google Classroom'u kullanmaya yönelik algılanan haz, öğrencilerin Google Classroom'a yönelik algılanan kullanışlılığını etkiler.

$\mathrm{H}_{3 \mathrm{~b}}$ :Google Classroom'u kullanmaya yönelik algılanan haz, öğretim elemanlarının Google Classroom'a yönelik algılanan kullanışlılığını etkiler.

$\mathbf{H}_{4}$ :Google Classroom'un özellikleri Google Classroom'un algılanan kullanım kolaylığını etkiler.

$\mathrm{H}_{4 \mathrm{a}}$ :Google Classroom'un özellikleri, öğrencilerin Google Classroom'un algılanan kullanım kolaylığını etkiler.

$\mathrm{H}_{4 \mathrm{~b}}$ :Google Classroom'un özellikleri, öğretim elemanlarının Google Classroom'un algılanan kullanım kolaylığını etkiler.

$\mathbf{H}_{5}$ : Google Classroom'un özellikleri Google Classroom'u kullanmaya yönelik algılanan hazzı etkiler.

$\mathrm{H}_{5 \mathrm{a}}$ :Google Classroom'un özellikleri, öğrencilerin Go-

Tablo 1.Frekans ve Yüzde Analizi-Öğrenci

\begin{tabular}{|c|c|c|c|}
\hline Değişken & $f$ & $\%$ & \\
\hline \multirow{2}{*}{ Cinsiyet } & Kadın & 263 & 53,9 \\
\hline & Erkek & 225 & 46,1 \\
\hline \multirow{4}{*}{ Yaş } & $18-22$ & 418 & 85,7 \\
\hline & $23-27$ & 58 & 11,9 \\
\hline & $28-32$ & 5 & 1,0 \\
\hline & 33 ve üstü & 7 & 1,4 \\
\hline \multirow{17}{*}{$\begin{array}{l}\text { Fakülte/Yüksekokul/ } \\
\qquad \text { MYO }\end{array}$} & Boğazlıyan Meslek Yüksekokulu & 40 & 8,2 \\
\hline & Eğitim Fakültesi & 3 & 6 \\
\hline & Fen Edebiyat Fakültesi & 102 & 20,9 \\
\hline & İktisadi ve İdari Bilimler Fakültesi & 37 & 7,6 \\
\hline & İlahiyat Fakültesi & 16 & 3,3 \\
\hline & İletişim Fakültesi & 68 & 13,9 \\
\hline & Mühendislik- Mimarlık Fakültesi & 4 & 8 \\
\hline & Sağlık Bilimleri Fakültesi & 1 & ,2 \\
\hline & $\begin{array}{l}\text { Sağlık Hizmetleri Meslek Yükseko- } \\
\text { kulu }\end{array}$ & 1 & ,2 \\
\hline & Sosyal Bilimler Meslek Yüksekokulu & 97 & 19,9 \\
\hline & Spor Bilimleri Fakültesi & 7 & 1,4 \\
\hline & Şefaatli Meslek Yüksekokulu & 8 & 1,6 \\
\hline & Teknik Bilimler Meslek Yüksekokulu & 39 & 8,0 \\
\hline & Tıp Fakültesi & 27 & 5,5 \\
\hline & Veteriner Fakültesi & 1 & ,2 \\
\hline & Yerköy Adalet Meslek Yüksekokulu & 17 & 3,5 \\
\hline & Ziraat Fakültesi & 20 & 4,1 \\
\hline \multirow{2}{*}{ Öğrenim Türü } & 1.öğrenim & 418 & 85,7 \\
\hline & 2.öğrenim & 70 & 14,3 \\
\hline \multirow[t]{6}{*}{ Sinıf } & hazırlık & 1 & ,2 \\
\hline & 1 & 248 & 50,8 \\
\hline & 2 & 116 & 23,8 \\
\hline & 3 & 58 & 11,9 \\
\hline & 4 & 64 & 13,1 \\
\hline & 5 & 1 & ,2 \\
\hline
\end{tabular}

ogle Classroom'u kullanmaya yönelik algılanan hazzını etkiler.

$\mathrm{H}_{5 \mathrm{~b}}$ :Google Classroom'un özellikleri, öğretim elemanlarının Google Classroom'u kullanmaya yönelik algılanan hazzını etkiler.

Çalışmanın belirlenen hipotezleri hem öğrenen grup olarak öğrenciler hem de öğreten grup olarak öğretim elemanları açısından ayrı ayrı değerlendirilmiştir.

\section{ANALIZ VE BULGULAR}

Araştırmanın analiz aşamasında SPSS 20.0 istatistik paket programı kullanılmıştır. Öncelikle veri setine ilişkin tanımlayıcı istatistiklere yer verilmiştir. Hipotezlerin test edilmesi aşamasında ise regresyon analizi kullanılmıştır. Veri setlerine ilişkin tanımlayıcı istatistikler Tablo 1, 2, 3 ve 4'de yer almaktadır.

Tablo 2.Frekans ve Yüzde Analizi-Öğretim Elemanı

\begin{tabular}{|c|c|c|c|}
\hline Değişken & Grup & $\mathrm{N}$ & $\%$ \\
\hline \multirow{2}{*}{ Cinsiyet } & Kadın & 60 & 48,4 \\
\hline & Erkek & 64 & 51,6 \\
\hline \multirow{5}{*}{ Yaş } & $22-31$ & 25 & 20,2 \\
\hline & $32-41$ & 69 & 55,6 \\
\hline & $42-51$ & 23 & 18,5 \\
\hline & $52-61$ & 6 & 4,8 \\
\hline & 62 ve üstü & 1 & 8 \\
\hline \multirow{2}{*}{ Medeni Durum } & Evli & 86 & 69,4 \\
\hline & Bekâr & 38 & 30,6 \\
\hline \multirow{20}{*}{ Akademik Birim } & Boğazlıyan Myo & 5 & 4,0 \\
\hline & Eğitim Fakültesi & 5 & 4,0 \\
\hline & Fen Edebiyat Fakültesi & 10 & 8,1 \\
\hline & İktisadi ve İdari Bilimler Fakültesi & 3 & 2,4 \\
\hline & İlahiyat Fakültesi & 7 & 5,6 \\
\hline & İletişim Fakültesi & 5 & 4,0 \\
\hline & Mühendislik- Mimarlık Fakültesi & 14 & 11,3 \\
\hline & Sağlık Bilimleri Fakültesi & 6 & 4,8 \\
\hline & $\begin{array}{l}\text { Sağlık Hizmetleri Meslek Yük- } \\
\text { sekokulu }\end{array}$ & 2 & 1,6 \\
\hline & $\begin{array}{l}\text { Sosyal Bilimler Meslek Yükse- } \\
\text { kokulu }\end{array}$ & 13 & 10,5 \\
\hline & Spor Bilimleri Fakültesi & 3 & 2,4 \\
\hline & Şefaatli Meslek Yüksekokulu & 10 & 8,1 \\
\hline & $\begin{array}{l}\text { Teknik Bilimler Meslek Yükse- } \\
\text { kokulu }\end{array}$ & 14 & 11,3 \\
\hline & Tıp Fakültesi & 2 & 1,6 \\
\hline & $\begin{array}{l}\text { Yabancı Diller Meslek Yükse- } \\
\text { kokulu }\end{array}$ & 1 &, 8 \\
\hline & $\begin{array}{l}\text { Yerköy Adalet Meslek Yükse- } \\
\text { kokulu }\end{array}$ & 8 & 6,5 \\
\hline & Ziraat Fakültesi & 3 & 2,4 \\
\hline & Akdağmadeni MYO & 7 & 5,6 \\
\hline & Çekerek Fuat Oktay SHMYO & 5 & 4,0 \\
\hline & Sorgun MYO & 1 &, 8 \\
\hline \multirow[t]{5}{*}{ Akademik Unvan } & Prof.Dr. & 2 & 1,6 \\
\hline & Doç.Dr. & 8 & 6,5 \\
\hline & Dr. Öğr. Üyesi & 38 & 30,6 \\
\hline & Öğretim Görevlisi & 67 & 54,0 \\
\hline & Araştırma Görevlisi & 9 & 7,3 \\
\hline Toplam & & 124 & 100,0 \\
\hline
\end{tabular}


Çalıșmada incelenen ilk örneklem birimi \%53,9'u kadın, \%46,1'i erkek olan öğrencilerden oluşmaktadır. Yaş aralığının \%85,7'si (418 kişi) 18-23 kategorisinde yer alarak katılımcıların büyük bir çoğunluğunu temsil etmektedir. Öğrenim gördükleri akademik birim açısından farklılıklar görülmekle beraber Fen- Edebiyat fakültesi (102 kişi), Sosyal Bilimler Meslek Yüksekokulu (97 kişi) ve İletişim Fakültesinin (68 kişi) ilk sıralarda yer aldığı görülmüştür. Birinci öğrenimin ağırlıklı olduğu ve katılımcıların yarısının birinci sınıfta $(\% 50,8)$ olduğu belirlenmiștir.

Çalıșmada incelenen ikinci örneklem birimi olan öğretim elemanlarının \%48,4'ü kadın, \%51,6’sı erkeklerden oluşmaktadır. Yaş aralığının \%55,6'sı (69 kişi) 32-41 kategorisinde yer alarak katılımcıların büyük bir çoğunluğunu oluşturmaktadır. Katılımcıların yaklaşık \%80'i evlidir. Görev yaptıkları akademik birim açısından farklılıklar görülmekle beraber Mühendislik-Mimarlık Fakültesi ve Teknik Bilimler Meslek Yüksekokulu (14 kişi) ilk sıralarda yer almıştır. Akademik unvan açısından katılımcıların \%54'ünün öğretim görevlisi, \%30,6’sının Dr. Öğr. Üyesi, \%7,3’ünün Araştırma Görevlisi, \%6,5'inin Doç. Dr. ve \%1,6'sının Prof. Dr. olduğu görülmüştür.

Tablo 3 ve 4'e göre araștırmanın veri setleri normal dağılım göstermektedir. Analiz öncesi veri setlerinin normal ya da normale yakın dağılım göstermesi sonuçların doğ-

Tablo 3.Ölçeklerin Tanımlayıcı İstatistikleri- Öğrenci

\begin{tabular}{|c|c|c|c|c|c|}
\hline $\begin{array}{c}\text { Ölçek } \\
\text { Ifade }\end{array}$ & Ortalama & $\begin{array}{c}\text { Standart } \\
\text { Sapma }\end{array}$ & Varyans & Çarpıklık & Basıklık \\
\hline AGCÖ1 & 3,9016 & 1,25356 & 1,571 &,- 944 &,- 161 \\
\hline AGCÖ2 & 3,6107 & 1,30708 & 1,708 &,- 603 &,- 739 \\
\hline AGCÖ3 & 3,6189 & 1,27936 & 1,637 &,- 594 &,- 645 \\
\hline AGCÖ4 & 3,5164 & 1,32568 & 1,757 &,- 495 &,- 867 \\
\hline AKK1 & 4,0738 & 1,21873 & 1,485 & $-1,283$ &, 659 \\
\hline AKK2 & 4,0553 & 1,18816 & 1,412 & $-1,206$ &, 505 \\
\hline AKK3 & 4,0184 & 1,18064 & 1,394 & $-1,178$ &, 528 \\
\hline AKK4 & 3,8668 & 1,28516 & 1,652 &,- 956 &,- 203 \\
\hline AKK5 & 4,0164 & 1,17457 & 1,380 & $-1,154$ &, 492 \\
\hline AKK6 & 4,1209 & 1,15517 & 1,334 & $-1,425$ & 1,281 \\
\hline AKK7 & 3,4037 & 1,34994 & 1,822 &,- 375 & $-1,002$ \\
\hline AKK8 & 3,4221 & 1,39450 & 1,945 &,- 446 & $-1,033$ \\
\hline AKK9 & 4,0533 & 1,10869 & 1,229 & $-1,213$ &, 835 \\
\hline AK1 & 3,6639 & 1,36161 & 1,854 &,- 679 &,- 789 \\
\hline AK2 & 3,1824 & 1,39136 & 1,936 &,- 168 & $-1,151$ \\
\hline AK3 & 3,3053 & 1,35452 & 1,835 &,- 313 & $-1,065$ \\
\hline AK4 & 3,7889 & 1,25027 & 1,563 &,- 868 &,- 248 \\
\hline AK5 & 3,7664 & 1,21707 & 1,481 &,- 821 &,- 238 \\
\hline AK6 & 3,5697 & 1,38311 & 1,913 &,- 622 &,- 851 \\
\hline AK7 & 3,4775 & 1,35924 & 1,848 &,- 477 &,- 972 \\
\hline AH1 & 2,9426 & 1,47421 & 2,173 &, 057 & $-1,364$ \\
\hline AH2 & 2,9672 & 1,60177 & 2,566 &,- 007 & $-1,558$ \\
\hline AH3 & 2,8320 & 1,59454 & 2,543 &, 143 & $-1,527$ \\
\hline AN1 & 3,1701 & 1,58981 & 2,527 &,- 204 & $-1,506$ \\
\hline AN2 & 2,9795 & 1,56042 & 2,435 &,- 018 & $-1,494$ \\
\hline AN3 & 3,0102 & 1,48016 & 2,191 &,- 037 & $-1,376$ \\
\hline AN4 & 3,5574 & 1,43181 & 2,050 &,- 615 &,- 950 \\
\hline N=488 & & & & & \\
\hline & & & & & \\
\hline
\end{tabular}

ru değerlendirilmesi açısından önem arz etmektedir.

\subsection{Araştırmanın Güvenirlik ve Geçerlilik Analizi}

Tablo 5'de öğrenci ve öğretim elemanlarına uygulanan anketlere ilişkin güvenirlik analizi ( $\alpha$ katsayısı) ve açımlayıcı faktör analizi sonuçları yer almaktadır. Tüm ölçeklerin her iki örneklem birimi için güvenirlik katsayılarının analizler için uygun olduğu görülmüştür. Aynı tabloda çalışmada yer alan ölçekler için $\mathrm{KMO}$ testi değeri $>0,50$ ve sig. değeri 0,000 olarak bulunmuştur, ölçeklere ilişkin ifadelerin faktör yüklerinin analize uygun nitelikte olduğu belirlenmiştir. Öğretim elemanlarının çalıșmanın modelinde yer alan değişkenlere ilişkin algılarının ortalama değerler açısından daha yüksek olduğu tespit edilmiştir.

\subsection{Regresyon Analizi ve Bulgular}

TKM çerçevesinde bir dijital öğrenme uygulaması olarak GC'nin öğrenciler ve öğretim elemanları açısından benimsenme düzeyinin belirlemek amacıyla yapılan bu çalışmanın hipotezlerini test etmek için yapılan regresyon analizi ve bulgular bu bölümde yer almaktadır. Analizler her iki örneklem birimi için ayrı ayrı yapılmıștır.

Çalışmanın modeline göre algılanan niyeti etkileyen temel faktör olarak varsayılan algılanan kullanış-

Tablo 4. Ölçeklerin Tanımlayıcı İstatistikleri- Öğretim Elemanı

\begin{tabular}{|c|c|c|c|c|c|}
\hline $\begin{array}{c}\text { Ölçek } \\
\text { Ifade }\end{array}$ & Ortalama & $\begin{array}{c}\text { Standart } \\
\text { Sapma }\end{array}$ & Varyans & Çarpıklık & Basıklık \\
\hline AGCÖ1 & 4,6694 &, 79349 &, 630 & $-2,906$ & 8,776 \\
\hline AGCÖ2 & 4,2581 &, 96163 &, 925 & $-1,321$ & 1,306 \\
\hline AGCÖ3 & 4,0806 &, 90703 &, 823 &,- 826 &, 281 \\
\hline AGCÖ4 & 3,8629 &, 95708 &, 916 &,- 738 &, 459 \\
\hline AKK1 & 4,3065 &, 88508 &, 783 & $-1,503$ & 2,479 \\
\hline AKK2 & 4,5565 &, 76830 &, 590 & $-2,434$ & 7,449 \\
\hline AKK3 & 4,4758 &, 80105 &, 642 & $-2,042$ & 5,284 \\
\hline AKK4 & 3,9597 & 1,09988 & 1,210 &,- 963 &, 160 \\
\hline AKK5 & 3,7984 & 1,18239 & 1,398 &,- 770 &,- 355 \\
\hline AKK6 & 4,2742 &, 91366 &, 835 & $-1,419$ & 1,981 \\
\hline AKK7 & 3,9194 & 1,03277 & 1,067 &,- 737 &,- 019 \\
\hline AKK8 & 4,0403 &, 95763 &, 917 &,- 815 &, 274 \\
\hline AKK9 & 4,3306 &, 83346 &, 695 & $-1,630$ & 3,516 \\
\hline AK1 & 4,1129 & 1,03758 & 1,077 & $-1,339$ & 1,533 \\
\hline AK2 & 3,9113 &, 98783 &, 976 &,- 900 &, 530 \\
\hline AK3 & 3,3468 & 1,03629 & 1,074 &,- 249 &,- 317 \\
\hline AK4 & 3,4274 & 1,13462 & 1,287 &,- 496 &,- 307 \\
\hline AK5 & 3,7258 & 1,05413 & 1,111 &,- 656 &,- 132 \\
\hline AK6 & 3,6452 & 1,07593 & 1,158 &,- 762 &, 323 \\
\hline AK7 & 3,7903 &, 92195 &, 850 &,- 518 &,- 180 \\
\hline AK8 & 3,9355 & 1,04175 & 1,085 & $-1,010$ &, 571 \\
\hline AH1 & 3,5645 & 1,14935 & 1,321 &,- 258 &,- 913 \\
\hline AH2 & 3,2903 & 1,28008 & 1,639 &,- 396 &,- 868 \\
\hline AH3 & 3,1694 & 1,27338 & 1,621 &,- 300 &,- 921 \\
\hline AN1 & 3,3306 & 1,39524 & 1,947 &,- 338 & $-1,153$ \\
\hline AN2 & 3,2500 & 1,31053 & 1,717 &,- 299 &,- 977 \\
\hline AN3 & 3,2903 & 1,23482 & 1,525 &,- 335 &,- 743 \\
\hline AN4 & 3,5806 & 1,09765 & 1,205 &,- 303 &,- 672 \\
\hline AN5 & 3,7016 & 1,14039 & 1,300 &,- 627 &,- 358 \\
\hline N=124 & & & & & \\
\hline & & & & & \\
\hline
\end{tabular}


Tablo 5.Güvenirlik Analizi ve Açımlayıcı Faktör Geçerlilik Analizi

\begin{tabular}{|c|c|c|c|c|c|c|}
\hline Grup & $\begin{array}{c}\text { Değişken } \\
\text { Ortala- } \\
\text { ma }\end{array}$ & $\begin{array}{l}\text { Alp- } \\
\text { ha } \\
\text { Kat- } \\
\text { sayısı }\end{array}$ & $\begin{array}{l}\text { KMO Örneklem } \\
\text { Yeterliliği Değeri }\end{array}$ & Ifade & $\begin{array}{l}\text { Faktör } \\
\text { Yükü } \\
\text { Öğrenci }\end{array}$ & $\begin{array}{l}\text { Faktör } \\
\text { Yükü } \\
\text { Öğretim } \\
\text { Elemanı }\end{array}$ \\
\hline & AGCÖ & & & AGCÖ1 & ,804 & ,793 \\
\hline \multirow{2}{*}{ Öğrenci } & \multirow{2}{*}{$M=3,66$} & \multirow{2}{*}{,883 } & \multirow{2}{*}{815} & AGCÖ2 & ,894 & 859 \\
\hline & & & & AGCÖ3 & 891 & 876 \\
\hline \multirow[t]{2}{*}{$\begin{array}{l}\text { Öğretim } \\
\text { Elemanı }\end{array}$} & $M=4,21$ & 863 & 767 & AGCÖ4 & ,852 & 841 \\
\hline & AKK & & & AKK1 & 841 & 834 \\
\hline \multirow{3}{*}{ Öğrenci } & \multirow{3}{*}{$M=3,89$} & \multirow{3}{*}{932} & \multirow{3}{*}{918} & AKK2 & ,782 & 831 \\
\hline & & & & AKK3 & 833 & 833 \\
\hline & & & & AKK 4 & ,821 & ,808 \\
\hline \multirow{6}{*}{$\begin{array}{l}\text { Öğretim } \\
\text { Elemanı }\end{array}$} & \multirow{5}{*}{$M=4,18$} & \multirow{5}{*}{926} & \multirow{5}{*}{895} & AKK5 & 857 & ,715 \\
\hline & & & & AKK6 &, 843 & 876 \\
\hline & & & & AKK7 & ,744 & 646 \\
\hline & & & & AKK8 & ,695 & ,788 \\
\hline & & & & AKK9 & 876 & 913 \\
\hline & \multicolumn{2}{|c|}{$A K$} & & $\mathrm{AK} 1$ & ,832 & 619 \\
\hline \multirow{2}{*}{ Öğrenci } & \multirow{2}{*}{$M=3,53$} & \multirow{2}{*}{933} & \multirow{2}{*}{918} & AK2 & 870 & 801 \\
\hline & & & & AK3 & 861 & 830 \\
\hline \multirow{6}{*}{$\begin{array}{l}\text { Öğretim } \\
\text { Elemanı }\end{array}$} & \multirow{5}{*}{$M=3,73$} & \multirow{5}{*}{910} & \multirow{5}{*}{906} & AK4 & 815 & 876 \\
\hline & & & & AK5 & 852 & ,751 \\
\hline & & & & AK6 & 848 & 854 \\
\hline & & & & AK7 & 840 & ,774 \\
\hline & & & & AK8 & $\ldots$ & 847 \\
\hline & $\mathrm{AH}$ & & & $\mathrm{AH} 1$ & ,720 & 856 \\
\hline Öğrenci & $M=2,91$ & 871 & 666 & $\mathrm{AH} 2$ & 890 & 967 \\
\hline \multirow[t]{2}{*}{$\begin{array}{l}\text { Öğretim } \\
\text { Elemanı }\end{array}$} & $M=3,43$ & 918 & 672 & $\mathrm{AH} 3$ & 890 & 954 \\
\hline & AN & & & AN1 & 861 & 883 \\
\hline \multirow{2}{*}{ Öğrenci } & \multirow{2}{*}{$M=3,17$} & \multirow{2}{*}{909} & \multirow{2}{*}{909} & AN2 & 883 & ,935 \\
\hline & & & & AN3 & 907 & 898 \\
\hline \multirow{2}{*}{$\begin{array}{l}\text { Öğretim } \\
\text { Elemanı }\end{array}$} & \multirow{2}{*}{$M=3,43$} & \multirow{2}{*}{929} & & AN4 & ,774 & ,798 \\
\hline & & & ,843 & AN5 & $\ldots$ & 906 \\
\hline Sig., 000 & & & & & & \\
\hline
\end{tabular}

lılık, öğrenci örnekleminde \%54,1 öğretim elemanın örnekleminde ise \%66,7 oranında algılanan niyeti aaçıkladığı tespit edilmiștir (Tablo 6). Analiz sonuçları doğrultusunda $\mathrm{H}_{1 \mathrm{a}}$ hipotezi $(\beta=, 878, \mathrm{p}<0,001), \mathrm{H}_{1 \mathrm{~b}}$ hipotezi $(\beta=, 781, p<0,001)$ kabul edilmiştir.

Algılanan kullanışlılık düzeyini, öğrenci örnekleminde \%66,4, öğretim elemanı örnekleminde $\% 48,6$ oranında algılanan kullanım kolaylığının açıkladığı görülmüștür. Algılanan haz değișkeninin ise öğrenci örnekleminde $\% 55,4$, öğretim elemanı örnekleminde $\% 64,5$ oranında algılanan kullanışlılık düzeyini açıkladığı belirlenmiştir (Tablo 7).

$\mathrm{Bu}$ değişkenlerin algılanan kullanışlılık düzeyi çerçevesinde etkilerinin pozitif ve anlamlı olduğu belirlenmiștir. $\mathrm{H}_{2 \mathrm{a}}, \mathrm{H}_{2 \mathrm{~b}}(\beta=, 925, \beta=, 767, \mathrm{p}<0,001)$ ve $\mathrm{H}_{3 \mathrm{a}}, \mathrm{H}_{3 \mathrm{~b}}$ $(\beta=, 603, \beta=, 581 \mathrm{p}<0,001)$ hipotezleri kabul edilmiștir. Algılanan kullanışlılık değişkenini, öğrencilerde algılanan kullanım kolaylığı faktörünün öğretim elemanlarında ise algılanan hazzın daha fazla oranda açıkladığı görülmüştür (Tablo7).

Çalışma kapsamında algılanan kullanım kolaylığına etkisi olduğu varsayılan GC'nin algılanan özellikleri, öğrencilerin verilerine göre bağımlı değișkeni \% 63, öğretim elemanlarının verilerine göre ise $\% 69,3$ oranında açıklamaktadır. $\beta_{\text {ö̆renci }}=, 780$ ve $\beta_{\text {öğrelm }}=, 821(\mathrm{p}<0,001)$ sonucuna göre Google Classroom'un algılanan özellikleri algılanan kullanım kolaylığına anlamlı ve pozitif yönde katkı sağlamaktadır. $\mathrm{H}_{4 \mathrm{a}}$ ve $\mathrm{H}_{4 \mathrm{~b}}$ hipotezleri kabul edilmiştir.

Tablo 9'da yer alan analiz sonuçlarına göre $\left(\beta_{\beta_{\text {ŏgrenci }}}=, 760\right.$ ve $\left.\beta_{\text {ö̆r.elm }}=, 861 ; \mathrm{p}<0,001\right) \mathrm{H}_{5 \mathrm{a}}$ ve $\mathrm{H}_{5 \mathrm{~b}}$ hipotezleri kabul edilmiştir. Google Classroom'un algilanan özellikleri bu

Tablo 6. Algılanan Kullanışlılığın Algılanan Niyete Etkisi

\begin{tabular}{|c|c|c|c|c|c|c|c|c|c|}
\hline & \multicolumn{3}{|c|}{ Model Özeti } & \multicolumn{4}{|c|}{ Etkiler } & \multicolumn{2}{|c|}{ ANOVA } \\
\hline & $\mathrm{R}$ & $\mathrm{R}^{2}$ & Durbin Watson & Standardize edilmemiş Beta & Std. Hata & Standardize Beta & $\mathrm{t}$ & $\mathrm{F}$ & Sig. \\
\hline $\begin{array}{c}\text { AK } \\
\text { Öğrenci }\end{array}$ & 736 &, 541 & 1,850 & 878 & ,037 & ,736 & 23,937 & 572,971 & 000 \\
\hline $\begin{array}{c}\text { AK } \\
\text { Öğretim Elemanı }\end{array}$ & ,816 & ,667 & 1,882 & 781 & ,050 & 816 & 15,620 & 243,970 & 000 \\
\hline
\end{tabular}

Tablo 7. Algılanan Kullanım Kolaylığı ve Algılanan Hazzın, Algılanan Kullanışıılığa Etkisi

\begin{tabular}{|c|c|c|c|c|c|c|c|c|c|}
\hline & \multicolumn{3}{|c|}{ Model Özeti } & \multicolumn{4}{|c|}{ Etkiler } & \multicolumn{2}{|c|}{ ANOVA } \\
\hline & $\mathrm{R}$ & $\mathrm{R}^{2}$ & Durbin Watson & Standardize edilmemiş Beta & Std. Hata & Standardize Beta & $\mathrm{t}$ & $\mathrm{F}$ & Sig. \\
\hline $\begin{array}{c}\text { AKK } \\
\text { Öğrenci }\end{array}$ & 815 & 664 & 1,897 & 925 & ,030 & 815 & 30,894 & 960,034 & 000 \\
\hline $\begin{array}{c}\text { AH } \\
\text { Öğrenci }\end{array}$ & ,745 &, 554 & 1,903 & ,603 & 025 &, 745 & 24,593 & 604,792 & 000 \\
\hline $\begin{array}{c}\text { AKK } \\
\text { Öğretim Elemanı }\end{array}$ & 697 & ,486 & 1,789 & ,767 & 071 & 697 & 10,744 & 115,428 & 000 \\
\hline $\begin{array}{c}\mathbf{A H} \\
\text { Öğretim Elemanı }\end{array}$ & 803 & ,645 & 1,750 &, 581 & 039 & 803 & 14,888 & 221,657 & 000 \\
\hline
\end{tabular}

Tablo 8. Algılanan Google Classroom Özelliklerinin Algılanan Kullanım Kolaylığına Etkisi

\begin{tabular}{|c|c|c|c|c|c|c|c|c|c|}
\hline & \multicolumn{3}{|c|}{ Model Özeti } & \multicolumn{4}{|c|}{ Etkiler } & \multicolumn{2}{|c|}{ ANOVA } \\
\hline & $\mathrm{R}$ & $\mathrm{R}^{2}$ & Durbin Watson & Standardize edilmemiş Beta & Std. Hata & Standardize Beta & $\mathrm{t}$ & $\mathrm{F}$ & Sig. \\
\hline $\begin{array}{l}\text { AGCÖ } \\
\text { Öğrenci }\end{array}$ & ,793 & ,630 & 2,016 & ,708 &, 025 & ,793 & 28,740 & 826,009 & ,000 \\
\hline $\begin{array}{c}\text { AGCÖ } \\
\text { Öğretim Elemanı }\end{array}$ & 833 & ,693 & 1,750 & 821 &, 049 & 833 & 16,606 & 221,657 & 000 \\
\hline
\end{tabular}


Tablo 9. Algılanan Google Classroom Özelliklerinin Algılanan Hazza Etkisi

\begin{tabular}{|c|c|c|c|c|c|c|c|c|c|}
\hline & \multicolumn{3}{|c|}{ Model Özeti } & \multicolumn{4}{|c|}{ Etkiler } & \multicolumn{2}{|c|}{ ANOVA } \\
\hline & $\mathrm{R}$ & $\mathrm{R}^{2}$ & Durbin Watson & Standardize edilmemiş Beta & Std. Hata & Standardize Beta & $\mathrm{t}$ & $\mathrm{F}$ & Sig. \\
\hline $\begin{array}{c}\text { AH } \\
\text { Öğrenci }\end{array}$ & ,607 & ,369 & 1,938 & ,760 & ,045 & ,607 & 16,860 & 284,256 & ,000 \\
\hline $\begin{array}{c}\mathbf{A H} \\
\text { Öğretim Elemanı }\end{array}$ &, 574 & ,330 & 2,028 & 861 & ,111 &, 574 & 7,744 & 59,969 & ,000 \\
\hline
\end{tabular}

uygulamaya ilişkin algılanan hazzı anlamlı ve pozitif olarak yönlendirmektedir.

\section{SONUÇ}

Dijitalleşme tüm sektörleri etkisi altına almakta ve olağanüstü durumlarda insanlığın yardımına koşmaktadır. Pandemi sürecinin dünyayı sarsan sonuçlarından biri de dijital teknoloji uygulamaların öneminin artmasıdır. Online ağırlıklı uygulamaların kullanım eğiliminin gelecekte yine bu seviyeye ulaşacağı düşünülmekle beraber salgın hastalığın bu süreci hızlandırdığı aşikârdır. Pek çok amaçla kullanılmaya başlanan dijital teknolojiler ve uygulamalar, eğitim, toplantı ve çeşitli görüşmelerin online olarak yapılması özelide eskisinden daha fazla kullanılmaktadır. Dijital platformların, kullanıcılarına göre tasarlanması ve erișim ağını genişletmesi dijitalleşme üzerine yatırımları da arttırmaktadır. Kullanıcıların uygulamalara ilişkin algıları ve benimseme düzeyleri de burada önem kazanmaktadır. Uygulama geliştirmek ve dijital platformlarda beklenen etkiyi gösterecek nitelikler kazandırılmak adına kullanıcıların bakıș açıları ürüne değer katmaktadır.

$\mathrm{Bu}$ araștırma, pandemi sürecinde yaygın kullanımı eğitim alanında olan dijital öğrenme ve öğretme uygulamalarından biri olarak Google Classroom'un benimsenmesini konu edinmektedir. Çalışma, TKM aracilığıyla öğrenciler ve öğretim elemanları açısından benimsenme düzeyini belirleyerek, mevcut ve potansiyel kullanıc1lara, sektör yatırımcılarına, programcılara uygulamanın etkinliği hakkında bilgi vermeyi hedeflemektedir. Araştırma 2019-2020 bahar döneminde uzaktan eğitim sürecine giren ve dijital platformda eğitim aracı olarak Google Classroom kullanılan Yozgat Bozok Üniversitesi’nde yapılmıştır. Öğrenciler ve öğretim elemanları için yeni olan bu dijital uygulamanın uzaktan eğitim sürecinde adaptasyonu belirlenmeye çalıșılmıștır. Pandemi beraberinde gelen uzaktan eğitim zorunluluğu, pek çok dijital platformu etkin kullanıyor olmasına rağmen dijital yerliler olarak nitelendirebileceğimiz ve internetin içine doğan öğrenci örneklemine bir dijital teknolojiden öğrenme deneyimi kazandırmıştır. Aynı zamanda çoğu dijital göçmenler sınıfında yer alan öğretim elemanları, kullandıkları farklı eğitim araçları yanında dijital öğretme sürecini başlatmıştır. Çalışma bu noktada, Google Classroom gibi bir dijital uygulamayı öğrenme ve öğretme amaciyla ilk defa aktif olarak kullanan bir örneklem grubuna yapılarak dijital uygulamaların geliștirilmesi açısında sonuçların önemini ortaya koymaktadır.
Çalışmanın sonuçları TKM değişkenleri yanında algılanan haz ve Google Classroom özellikleri çerçevesinde algılanan niyete etki düzeyinde değerlendirilmiştir. Öğrenci ve öğretim elemanları için Google Classroom'un erişilebilir olması, etkili bir iletişim ağı sunması, iyi bir yorum ağı ve geri bildirim sistemi oluşturması ve kullanıcı dostu arayüzü ile uygulamaya ilişkin algılanan kullanım kolaylığı ve hazzı anlamlı ve pozitif yönde etkilediği belirlenmiştir. Burada, dijitalleşme sürecinin içine doğan dijital yerliler (öğrenciler) için olduğu kadar göçmenler (öğretim elemanları) için de Google Classroom'un kullanıcısına sunduğu avantajlar sayesinde kullanımını kolaylaştırdığı̆, hem eğlendiren hem heyecanlandıran bir e-öğretim teknolojisi sunduğu söylenebilmektedir. $\mathrm{Bu}$ sonuç, algılanan kullanım kolaylığı ve algılanan haz değişkenleri üzerinde incelenen teknolojinin özelliklerinin pozitif ve anlamlı etkileri olduğu sonucunu ortaya çıkaran Balog ve Pribeanu (2010), Chen vd., (2013), Yang vd., (2011) çalışmalarına benzerlik göstermektedir.

Çalışmada algılanan kullanım kolaylığı ve algılanan haz değişkenlerinin, algılanan kullanışlılık düzeyi üzerinde etkilerine aynı modelde bakan çalışmalarla (Balog \& Pribeanu, 2010; Chen vd., 2013) benzer şekilde anlamlı ve pozitif etkisi olduğu sonucuna ulaşılmıştır. Ayrıca algılanan kullanım kolaylığının algılanan kullanışlılığı etkilediği çalışmaların (Al-Maroof \& Al-Emran, 2018; Shaharanee vd., 2016) sonuçları da bu çalışma ile paralellik göstermiştir. Bu sonuç geniş çapta kabul görmektedir çünkü bu iki yapı (algılanan kullanım kolaylığı ve algılanan kullanışlılık) bilgi sistemlerini veya yenilikçi ürünleri kullanma niyetinin öncülleri olarak değerlendirilmektedir (Wu \& Wang, 2005; Bruner vd., 2005). Google Classroom'un kurulum ve oturum açma kolaylığı, belge ve bilgi ekleme, hataları anında düzeltme, dokümanları değerlendirme, bilgi alışverişi gibi kullanım kolaylığı sunması gibi bazı özelliklerinin, faktör yüklerine göre kullanışlılığa etkisi olduğu görülmektedir. Özellikle algılanan haz değişkeninin içsel bir motivasyon faktörü olarak algılanan kullanışlılığa ve dolaylı olarak algılanan niyete etkisi burada önem kazanmaktadır.

Öğrenci örnekleminde algılanan kullanım kolaylığı, öğretim elemanı örnekleminde ise alğlanan haz değişkenlerinin algılanan kullanışlılığı etkileyen en güçlü değișkenler olduğu görülmüştür. Öğrenciler için uygulamayı telefon, tablet gibi mobilitesi yüksek cihazlarda kullanmak, öğretim elemanı ile iletişimini anlık sağlamak, ödev vb. dokümanları yüklemek açısından kullanışlılığı yüksek oranda etkilediği söylenebilmektedir. Öğretim elemanlarında hazzın ön plana çıkması, meslektaşlar ile 
grup çalışmaları olanağı, online görüşmeyi eğlenceli hale getiren bir takım avantajlar (sesli ve görüntülü konuşma vb.) nedeniyle olduğu düşünülmektedir. Burada, keyifli bir görüşme deneyiminin algılanan kullanışlılığı artırdığ1 söylenebilmektedir.

TKM'ye göre, algılanan niyet, belirli bir bilgi teknolojisi sisteminin gerçek kullanımını tanımlamakta ve bu nedenle teknoloji kabulünü ve benimsenme düzeyini belirlemektedir (Alharbi \& Drew, 2014). Google Classroom kullanımına yönelik niyeti doğrudan etkilediği varsayılan algılanan kullanışlılık değişkeninin, benzer araştırmalarda olduğu gibi (Al-Aulamie vd. 2012; Al-Maroof \& Al-Emran, 2018; Balog \& Pribeanu, 2010; Chen vd., 2013; Lee vd., 2005) bu çalışmada da örneklem birimlerinin algılanan niyet (benimseme) düzeyini anlamlı ve pozitif yönde etkilediği belirlenmiştir. Google Classroom'un uzaktan eğitim için yararlı bulunması, yan uzantılar ile hem görüntülü hem de sesli iletişim ağı sunarak etkileşimi arttırması, fiziksel mesafelere rağmen kaliteli bir görüşme ortamı sunması, senkronizasyon ve güçlü bir iletişim ağı gibi kullanışlı öğeler barındırmasının benimsenme düzeyini olumlu etkilediği söylenebilmektedir. Bu sayede uygulamanın salgın boyunca ve hatta salgın sonrasında da kullanımının öne çıktığ 1 , kullanımının tavsiye edildiği ve tüm bu özellikleri sayesinde motive edici bulunduğu da, ifadelerin ortalama değerleri paralelinde, sonuçlar arasında yer almaktadır.

Bu araştırma pek çok dijital alanda sektörün öncüsü olan Google tarafından geliştirilen bir dijital öğrenme ve öğretme platformu için çeşitli değerlendirme boyutlarını, Google Classroom'u henüz kullanan YOBÜ bünyesinde ele almıştır. Google Classroom'a uyarlanan çalışma modelinin kullanıcı merkezli biçimlendirici bir değerlendirme olarak, program geliştiricilere, yazılımcılara ve teknoloji yatırımcılarına hatta kendi dijital platformlarını kullanmak isteyen kamu ve özel üniversitelerine kullanılabilirlik, kullanışlılık ve kullanıcı deneyimi hakkında hızlı bir geri bildirim sağlayacağı varsayılmaktadır. Çalışmanın, dijital pazarda böyle bir ürünle var olmak isteyen girişimcilerin firsatları değerlendirmesi yönünde referans olduğu, ayrıca e-öğrenme sistemlerinin içsel motivasyonel değerini belirlemek adına literatüre katkı sunduğu düşünülmektedir.

Gelecekte yapılacak çalışmalarda değişkenlerin etkileri yapısal eşitlik modellemesi ile araştırılması önerilmektedir. Özellikle algılanan haz değişkeninin aracılık rolü ön plana çıkabilmektedir. Bu araştırma yalnızca YOBÜ’yü kapsamaktadır ve TKM çerçevesindeki değişkenler aracılığı ile benimsenme düzeyi (algılanan niyet) belirlenmeye çalışılmıştır. Farklı modeller ve değişkenler ile dijital teknolojilerin farklı alanlarda benimsenme düzeyinin ölçülmesi, demografik faktörler açısından gruplar arası farklılıklara bakılması, davranışsal niyetin değerlendirilmesi açısından gelecekteki çalışmalara önerilmektedir. İçinde bulunduğumuz COVID-19 süreci dışında eğitim alanında yenilikçi bakış açısı kazanmak isteyen birimlerin, yakın gelecekte ve pandemi sonrası süreçte, bu tarz dijital uygulamaları sistemlerine dahil ederek hibrid modeller ile uygulamalarını zenginleştirmeleri önerilmektedir. Sürdürülebilir bir öğrenim sürecinin bundan sonraki yüzyıllar için en temel özelliğinin teknolojiye hizalanmak olduğu düşünülmektedir.

\section{KAYNAKÇA}

Akyürek, M. İ. (2020). Uzaktan eğitim: bir alanyazın taraması, Medeniyet Eğitim Araştırmaları Dergisi, 4 (1), 1-9. Erişim adresi: https://dergipark.org.tr/en/download/article-file/1029473

Al-Aulamie, A., Mansour, A., Daly, H. \& Adjei, O. (2012). The effect of intrinsic motivation on learners' behavioral intention to use e-learning systems, In International Conference on Information Technology Based Higher Education and Training (ITHET), IEEE, 1-4. doi: 10.1109/ITHET.2012.6246057

Alharbi, S. \& Drew, S. (2014). Using the technology acceptance model in understanding academics' behavioural intention to use learning management systems, (IJACSA) International Journal of Advanced Computer Science and Applications, 5(1), 143-155. doi: 10.14569/IJACSA.2014.050120

Al-Maroof, R. A. S. \& Al-Emran, M. (2018). Students acceptance of google classroom: an exploratory study using pls-sem approach, International Journal of Emerging Technologies in Learning (iJET), 13(6), 112-123. doi: 10.3991/ijet. v13i06.8275

Arat, T. \& Bakan, Ö. (2011). Uzaktan eğitim ve uygulamaları, Selçuk Üniversitesi Sosyal Bilimler Meslek Yüksekokulu Dergisi, 14 (1-2), 363-374. Erişim adresi: https://dergipark.org.tr/en/ download/article-file/116745

Azhar, K. A. \& lqbal, N. (2018). Effectiveness of google classroom: teachers' perceptions, Prizren Social Science Journal, 2(2), 52-66. Retrieved from https://www.researchgate.net/ publication/327417783_Effectiveness_of_Google_Classroom_Teachers'_Perceptions/link/5b91fe96a6fdccfd541f8ea1/download

Balog, A. \& Pribeanu, C. (2010). The role of perceived enjoyment in the students' acceptance of an augmented reality teaching platform: A structural equation modelling approach, Studies in Informatics and Control, 19(3), 319- 330. doi: 10.24846/v19i3y201011

Bhat, S., Raju, R., Bikramjit, A. \& D'souza, R. (2018). Leveraging e-learning through google classroom: a usability study, Journal of Engineering Education Transformations, 31(3), 129-135. doi: 10.16920/jeet/2018/v31i3/120781

Bruner II, G. C. \& Kumar, A. (2005). Explaining consumer acceptance of handheld internet devices, Journal of Business Research, 58(5), 553-558. doi: 10.1016/j.jbusres.2003.08.002

Chang, S., Chou, C. \& Yang, J. (2010). The literature review of technology acceptance model: A study of the bibliometric distributions, PACIS 2010 Proceedings, 1634-1640. Retrieved from https://aisel.aisnet.org/cgi/viewcontent.cgi?article $=1156$ vecontext $=$ pacis 2010

Chen, Y. C., Lin, Y. C., Yeh, R. C. \& Lou, S. J. (2013). Examining factors affecting college students' intention to use web-based 
instruction systems: Towards an integrated model, Turkish Online Journal of Educational Technology, 12(2), 111-121. doi: 10.14456/hasss.2020.10

Davis, F. D. (1989). Perceived usefulness, perceived ease of use, and user acceptance of information technology, MIS Quarterly, 13(3), 319-340. doi: 10.2307/249008.

Dykes, A. (2020), What Is Google Classroom. Retrieved from https://www.webopedia.com/definitions/google-classroom/\#what-is-google-classroom

Fitriningtiyas, D. A., Umamah, N. \& Sumardi (2019). Google classroom: As a media of learning history, IOP Conference Series Earth and Environmental Science, 243(1), 1-8. doi:10.1088/1755-1315/243/1/012156.

Garda, B. \& Temizel, M. (2016). Bilgi çağında eğitim, Selçuk Üniversitesi Sosyal ve Teknik Araştırmalar Dergisi, 12, 23-43. Erişim adresi: http://sosyoteknik.selcuk.edu.tr/sustad/article/view/85/67

Gupta, A. \& Pathania, P. (2021). To study the impact google classroom: As a media of learning history of google classroom as a platform of learning and collaboration at the teacher education level, Education and Information Technologies, 26, 843-857. doi:10.1007/s10639-020-10294-1

Haşıloğlu, S. B., Baran, T. \& Aydın, O. (2015). Pazarlama araştırmalarındaki potansiyel problemlere yönelik bir araştırma: kolayda örnekleme ve sıklık ifadeli ölçek maddeleri, PIBYD, 2(1), 19-28. Erişim adresi: https://dergipark.org.tr/tr/pub/ pibyd/issue/35465/394010

Heggart, K. R., \& Yoo, J. (2018). Getting the most from google classroom: A pedagogical framework for tertiary educators. Australian Journal of Teacher Education, 43(3), 140153. doi: 10.14221/ajte.2018v43n3.9

Hong, S. H., \& Yu, J. H. (2018). Identification of external variables for the technology acceptance model (TAM) In the assessment of BIM application for mobile devices. 2nd International Conference on Architecture and Civil Engineering (ICACE), IOP Publishing, 401(1), 1-5. doi:10.1088/1757899X/401/1/012027

Internet World Stats, (2021). Usage and population statistics. Retrieved from https://www.internetworldstats.com/ stats.htlm

İşman, A. (2011). Uzaktan eğitim, Geliştirilmiş 4. Baskı, Pegem Akademi.

Korucu, A. T. \& Biçer, H. (2019). Mobil öğrenme: 2010-2017 çalışmalarına yönelik bir içerik analizi, Trakya Eğitim Dergisi, 9 (1), 32-43. doi:10.24315/tred.516911

Lee, M., Cheung, C. \& Chen, Z. (2005). Acceptance of internet-based learning medium: the role of extrinsic and intrinsic motivation, Information ve Management, 42(8), 1095-1104. doi: 10.1016 / j.im.2003.10.007

Limayem, M., Hirt, S. G. \& Chin, W. G. (2001). Intention does not always matter: The contingency role of habit on IT usage behavior, Global Co-Operation in the New Millennium 9th European conference on information systems (ECIS 2001), 274-286. Retrieved from https://aisel.aisnet.org/cgi/ viewcontent.cgi?article $=1070$ vecontext $=$ ecis 2001

Mubuke, F., Ogenmungu, C., Mayoka, K. G., Masaba, A. K. \& Andrew, W. (2017). The predictability of perceived enjoyment and its impact on the intention to use mobile learning systems, Asian Journal of Computer Science And In- formation Technology, 7(1), 1-5. doi:10.15520/ajcsit.v6i8.51

Pappas, C. (2015), Google classroom review: pros and cons of using google classroom in elearning. Retrieved from https://elearningindustry.com/google-classroom-review-pros-and-cons-of-using-google-classroom-in-elearning

Park, S. Y. (2009). An analysis of the technology acceptance model in understanding university students' behavioral intention to use e-learning, Educational Technology ve Society, 12(3), 150-162. Retrieved from https://www.jstor. org/stable/10.2307/jeductechsoci.12.3.150

Sarıtaş, E. \& Barutçu, S. (2020). Öğretimde dijital dönüşüm ve öğrencilerin çevrimiçi öğrenmeye hazır bulunuşluluğu: pandemi döneminde pamukkale üniversitesi öğrencileri üzerinde bir araştırma, IUYD, 11 (1), 5-22. doi: 10.34231/ iuyd.706397

Shaharanee, I. N. M., Jamil, J. M. \& Mohamad Rodzi, S. S. (2016). Google classroom as a tool for active learning, AIP Conference Proceedings 1761, 020069, 1-6. doi: 10.1063/1.4960909

Shaharanee, I. N. M., Jamil, J. M. \& Mohamad Rodzi, S. S. (2016). The application of google classroom as a tool for teaching and learning, Journal of Telecommunication, Electronic and Computer Engineering, 8(10), 5-8. Retrieved from https://journal.utem.edu.my/index.php/jtec/article/ view/1357/882

Simonson, M., Schlosser, C. \& Orellana, A. (2011). Distance education research: A review of the literature. Journal of Computing in Higher Education, 23(2), 124-142. doi: 10.1007/ s12528-011-9045-8

Sudarsana, I. K., Putra, I. B. M. A., Astawa, I. N. T. \& Yogantara, I. W. L. (2019). The use of google classroom in the learning process, Journal of Physics: Conference Series. IOP Publishing,1175(1). doi: 10.1088/1742-6596/1175/1/012165

Suki, N.M. \& Suki, N.M. (2011). Exploring the relationship between perceived usefulness, perceived ease of use, perceived enjoyment, attitude and subscribers' intention towards using 3G mobile services, Journal of Information Technology Management, XXII(1), 1-7. Retrieved from http://jitm.ubalt.edu/XXII-1/article1.pdf

Tabata, L. N. \& Johnsrud, L. K. (2008). The impact of faculty attitudes toward technology, distance education, and innovation. Research In Higher Education, 49(7), 625-646. doi: 10.1007/s11162-008-9094-7

Taşkıran, A. (2017). Dijital çağda yükseköğretim, Açık Öğretim Uygulamaları ve Araştırmaları Dergisi, 3(1), 96-109. Erişim adresi: https://dergipark.org.tr/en/download/article-file/402573

Tekin Poyraz, G. \& Özkul, A. E. (2019). Bir öğrenme ortamı olarak google sınıf'ın incelenmesi, Açıköğretim Uygulamaları ve Araştırmaları Dergisi, 5 (3), 8-27. Erişim adresi: https:// dergipark.org.tr/en/download/article-file/853587

Telli Yamamoto, G. \& Altun, D. (2020). Coronavirüs ve çevrimiçi (online) eğitimin önlenemeyen yükselişi, Üniversite Araştırmaları Dergisi, 3 (1), 25-34. doi: 10.32329/uad.711110

Uyar, A. (2019). Tüketicilerin mobil uygulamalara ilişkin algılarının teknoloji kabul modeli ile değerlendirilmesi, İşletme Araştırmaları Dergisi, 11(1), 687-705. doi: 10.20491/isar- 
der.2019.629

Ünlü, M. (2019). Dijital çağda e-öğrenme ortamlarının kalitesini artırmaya yönelik gerçekleştirilen uluslararası çalışmalar, Ufuk Üniversitesi Sosyal Bilimler Enstitüsü Dergisi, 8 (16), 165-182. Erişim adresi: https://dergipark.org.tr/en/download/article-file/1476301

Wu, J. H. \& Wang, S. C. (2005). What drives mobile commerce?: An empirical evaluation of the revised technology acceptance model, Information ve management, 42(5), 719-729. doi: 10.1016/j.im.2004.07.001

Yang S.Y., Fang H.C., Chuang, C. \& Li, H. A. (2011). Applying the technology acceptance model to investigate consumers' acceptance of digital learning system, Energy Procedia, 13, 3166-3173. doi: 10.1016/j.egypro.2011.11.459 